\title{
INFLUENCE OF DIETARY INCLUSION OF PHYTOBIOTICS ON GROWTH PERFORMANCE, CARCASS AND ORGAN WEIGHT OF BROILER CHICKENS
}

\author{
W. A. Olayemi ${ }^{\mathbf{}^{*}}$; G. A. Williams ${ }^{2}$; O.P. Olatidoye ${ }^{\mathbf{3}}$; E.O. Omofunmilola ${ }^{\mathbf{1}}$ \\ ${ }^{1}$ Department of Agricultural Technology, Yaba College of Technology, Yaba, Lagos, Nigeria. \\ ${ }^{2}$ School of Agriculture, Lagos State University, Epe, Lagos, Nigeria. \\ ${ }^{3}$ Department of Food Technology, Yaba College of Technology, P.M.B 2011, Lagos, Nigeria \\ *Corresponding author: w_olayemi@yahoo.co.uk, +2348023671812
}

\begin{abstract}
This study investigated the dietary inclusion effect of three Phytobiotics: Syzygium aromaticum (Cloves), Piper nigrum (Black pepper) and Tetrapleura tetraptera (Prekese) on performance, carcass traits and organ weight of broile rchickens. Two hundred-day old unsexed broilers were used for the study. The birds were allotted on weight equalization basis to four dietary treatments (T1, T2, T3 and T4) in Completely Randomized Design. Each treatment was replicated five times with 10 birds per replicate. Four experimental diets were formulated for each of starter and finisher phase respectively. Control diet (T1) with no phytogenic inclusion while T2, T3 and T4 were formulated with inclusion of 1\% Syzygium aromaticum (Cloves), Piper nigrum (Black pepper) and Tetrapleura tetraptera (Prekese) respectively; and the experiment lasted for 8 weeks (4weeks for each phase). Feed intake, Weight gained and Feed conversion ratio were measured at starter and finisher phases while carcass and organ weight measurements were carried out at the end of finisher phase. Dietary inclusion of phytogenics recorded similar $(P>0.05)$ values of growth performance parameters at starter phase whereas a significant $((P<0.05)$ effect were observed on weight gain, FCR, Live weight and plucked weight at finisher phase. It was observed that inclusion of cloves had improvement on final weight $(F W)$, weight gain $(W G)$ and FCR with higher $(P<0.05)$ plucked weight.
\end{abstract}

Key words: Finisher premix, daily feed intake, feed conversion ratio, cloves, black pepper https://dx.doi.org/10.4314/jafs.v18i2.2

\section{INTRODUCTION}

The minimization to total prohibition on the use of antibiotics due to their side effect has been the trend of practice particularly in broiler production which has given rise to the use of natural growth promoters like probiotics, prebiotics, phytogenics and other feed additives to achieve improved performance (Borazjanizadeh et al, 2011). These alternatives to antibiotics play effective role in antibacterial activity thereby influencing improved gut health for enhanced performance (Schone et al., 2006). In recent times, phytogenic plants have gained much attention as feed additive as a result of having the efficacy of reducing bacteria load and increasing digestive secretions (Reisinger et al., 2011). These phytogenic plants consist of bioactive compounds such as allicin, thymol, carvacol, anethole and allyl-isothiocyanate 
that are potent in promoting poultry health and enhancing growth (Hippenstiel et al., 2011). Phytogenic feed additives have been reported to enhance performance and improve nutrient digestibility (Mountzouris et al., 2011). Black pepper (Piper nigrum), Aidan fruit (Tetrapleura tetraptera) and Clove (Syzygium aromaticum) belong to this group of plants which are capable of stimulating digestive enzymes thereby enhancing growth of poultry birds (Akbarian et al., 2013; Hong et al., 2012) and have been used in animal and poultry production due to their health benefits. It has the ability to enhance the function of the digestive tract thereby improving digestion through stimulating the secretion from taste buds (Duessel et al., 2008). Research studies involving animal models also reveals that black pepper and its active constituents piperine possess anti-oxidant, anti-inflammatory, antimicrobial and neuroprotective properties (Monika et al., 2010). Aidan fruit (Tetrapleura tetraptera) locally known as prekese has been used as a medicine and as a supplement rich in vitamins (Abugri and Pritchett, 2013). Aidan fruit shell and seed have been reported to be rich inprotein, lipids and minerals similar to some popular plants such as red pepper and ginger as well as cinnamic acids which is a precursor for the synthesis of plant substances including lignin and flavonoids that exhibit antibacterial properties (Akin-Idowu et al., 2011). It also contains caffeic acid which is a type of polyphenol known for antioxidant properties and carbohydrates (Adewunmi, 1999). Cloves perform various functions including improving digestion, protection against internal parasites and as antimicrobial agents against fungi (Burt and Reinders, 2003). Syzygium species have also been reported to possess antibacterial and anti-inflammatory activity (Shafi et al, 2002) with its positive influence on bird's performance. Cross et al., (2007) reported positive influence of phytogenic additives on broiler weight gain, feed conversion ratio and gut microflora. In contrary, Nasir and Grashorn (2010) in their studies with Echinacea purpurea and Nigella sativa supplementation in broiler had no effects on body weight gain and feed intake. Hafeez et al. (2016) reported that supplementation of broiler diet with a mixture of encapsulated essential oils were superior to the tested Phytogenic feed additives in powdered form. To this end, despite the promising potentials and substantial attention given to phytogenic plants there have been inconsistent reports and discrepancies in terms of the efficacy of these plants in influencing performance and carcass yield of broilers. Therefore, this study seeks to investigate the dietary inclusion effect of cloves, Black pepper and Prekese fruit on performance, carcass and organ weight of broilers.

\section{MATERIALS AND METHODS}

\section{Experimental Location:}

The study was carried out at the Teaching and Research Farm of the Department of Agricultural Technology, Yaba College of Technology, Epe. The site is on latitude $6.58{ }^{\circ} \mathrm{N}$, Longitude $3.98{ }^{\circ} \mathrm{E}$ It lies in the low land rain forest within the savannah agro- ecological zoneswith annual rainfall of $1694 \mathrm{~mm}$ and temperature of $27.1^{\circ} \mathrm{C}$ (Google Earth, 2019).

\section{Preparation of the Test Ingredients}

The test ingredients; Syzygium aromaticum, Piper nigrum and Tetrapleura tetraptera were purchased from Agege market, Lagos state, Nigeria. They were sun dried to 10-12\% moisture

Journal of the Faculty of Agriculture and Veterinary Medicine, Imo State University Owerri website: www ajol.info; Attribution: Non-commercial CC BY-NC 
content with the assumption that sun drying does not deplete their nutrient values. The ingredients were milled to particle size of $0.2 \mathrm{~mm}$ using Kenwood blender. The milled test ingredients were stored in plastic bags prior to diet formulation.

\section{Experimental Birds, Design and Dietary Treatment}

Two hundred day-old unsexed broiler (Cobb) chicks were obtained from a reputable commercial hatchery for this study. The brooding was done under a deep litter system and the day-old chicks were allotted on weight equalization basis to four dietary treatments (T1, T2, T3 and T4). Each treatment was replicated five times with 10 birds per replicate in a completely randomized design (CRD). The experiment lasted for eight weeks during which feed and water were given ad libitum. Newcastle disease and Infectious bursal disease vaccines were given while vitamin and anti-coccidial were administered. Four experimental diets were formulated for each of starter (Table 1) and finisher (Table 2) phases. Control diet (T1) contains no phytogenic inclusion while T2, T3 and T4 were formulated with inclusion of Syzygium aromaticum (Cloves), Piper nigrum (Black pepper) and Tetrapleura tetraptera (Prekese) respectively. The test ingredients; Syzygium aromaticum, Piper nigrum and Tetrapleura tetraptera were added to the feed at $1 \%$ and the diets were formulated based on nutrient requirement of broiler chickens (NRC, 1994).

\section{Data collection}

\section{Growth Performance}

Growth performance of the broiler chickens were monitored and determined by measuring their weights, feed intake and feed conversion ratio (FCR).

\section{Body weight gain $(\mathrm{g})$}

The initial body weights of the broiler chicks were taken on arrival and subsequent body weight gain were recorded at the end of every week for a period of 8 weeks of the experiment. Body weight gain was calculated from the differences between the body weight gain for the given week and previous week. Final body weights of the birds were taken at the end of the experiment and recorded.

Daily body weight gain $(\mathrm{g})=$ Final body weight $(\mathrm{g})$ - Initial weight gain $(\mathrm{g})$

$$
\text { Total number of days of experiment (56 days) }
$$

\section{Feed consumption/intake (g)}

A known quantity of feed was given to the broiler chicken while the leftover of the feed was weighed to determine daily feed intake for each treatment. Feed intake for each week was obtained from differences between the feed given per week and leftover.

Total feed intake $(\mathrm{g})=$ daily feed intake multiplied by 56 days .

Feed conversion ratio (FCR): The feed conversion ratio of the birds was determined by calculating the ratio of their feed intake to weight gain

$$
\mathbf{F C R}=\frac{\text { Total feed intake }(\mathrm{g})}{\text { Total body weight gain }(\mathrm{g})}
$$




\section{Carcass and organ weights}

At the end of the $8^{\text {th }}$ week feeding trial, a bird per replicate ( 5 birds per treatment) whose weight is similar or close to the average weight of the birds in each replicate were slaughtered for carcass analysis. Feed were withdrawn $12 \mathrm{~h}$ prior the selection of birds for carcass analysis. The slaughtered broiler chickens were de-feathered and eviscerated to evaluate their carcasses according to Jensen (1984). The carcasses were weighed and weights of Cut parts which include head, neck, breast, back, thighs, drum sticks and shanks were weighed and recorded as relative weights (\% live weight). The organs which includes kidney, lungs, gizzard, liver, heart, and proventriculus were also weighed using a sensitive weighing scale Salte ${ }^{\circledR}$ electronic balance with sensitivity of $0.01 \mathrm{~g}$ ) and the weights of organs and cut parts were expressed as percentages of live weight.

\section{Statistical analysis}

Data obtained from the study were subjected into one-way analysis of variance (ANOVA) in a completely randomized design using the General linear modelling (GLM) procedure of statistical analysis software $S_{A S}{ }^{\circledR}$ version 2000. Significantdifferences among treatment means were determined using Duncan Multiple Range Test (DMRT) as contained in the SAS software.

\section{RESULTS}

Growth performance at starter phase: Table 3 shows the result of dietary inclusion OF phytogenic plants inclusion on performance of broiler chickens at starter phase. The Table shows no significant $(\mathrm{P}>0.05)$ effect of phytogenic plants inclusion on growth performance parameters measured.

Growth performance at finisher phase: The effect of dietary phytogenic plant inclusion on performance of broilers at finisher phase is presented in Table 4. There was significant $(\mathrm{P}<0.05)$ phytogenic plants inclusion on weight gain $(\mathrm{WG})$ and feed conversion ratio $(\mathrm{FCR})$ while daily feed intake and initial weights were not significantly $(\mathrm{P}>0.05)$ different. Broilers fed diet containing cloves had higher $(\mathrm{P}<0.05) \mathrm{FW}$ and WG compared to those fed control diet and those fed diet containing black pepper but similar $(\mathrm{P}>0.05)$ to those fed diet containing prekese. Significantly $(\mathrm{P}<0.05)$ lower FCR was recorded for broilers fed diet containing cloves compared to other treatments, while broilers fed $\mathrm{T} 1$ diet recorded significantly $(\mathrm{P}<0.05)$ higher $\mathrm{FCR}$ than $\mathrm{T} 2, \mathrm{~T} 3$ and $\mathrm{T} 4$.

Carcass and organ weight of broiler chickens: Table 5 shows the result of dietary phytogenic plant inclusion on carcass characteristics and organ weights of the broiler chickens. The result shows significant $(\mathrm{P}<0.05)$ effect of phytogenic inclusion on live weight, de-feathered weight and neck weight of broilers only. Broilers fed diet containing cloves had higher $(\mathrm{P}<0.05)$ live weight and plucked weight compared to those fed control diet and those fed diet containing prekese. Neck weight was higher $(\mathrm{P}<0.05)$ in birds fed diet containing black pepper than those fed diet containing cloves. 


\section{DISCUSSION}

Research studies have documented the use of phytogenic inclusion to be useful as a growth promoter due to its active constituents (Kim et al., 2015; Elagib et al., 2013). As observed, dietary inclusion of phytogenic plants has no significant effect on weight gain, feed intake and feed conversion ratio at starter phase. Though, a numerical increase was observed in feed intake, weight gain and improved FCR of broilers fed diet containing cloves, this might be due to the potential of phytogenic compounds to increase feed intake through enhancing palatability of the diet due to enhanced flavour and odour (Kroismay et al., 2006). This observation was similar to a recent study by Mahrous et al., (2017) that no significant differences in body weight gain and feed conversion ratio in broiler chickens fed clove bud supplements at a rate of 0.5 and $1.0 \mathrm{~g} / \mathrm{kg}$ diet. Amad et al., (2013) also observed no significant effect of commercial phytogenic additives on performance of broiler at starter phase. This may be caused by the antinutritional factor such as tannin, which is responsible for reducing body weight in young birds (Onu, 2010) as young birds are more sensitive to antinutritional factors than older ones. At finisher phase; feed intake across treatments were numerically similar but weight gain and FCR were significant which is in line with Taxi et al. (2014) that broiler chickens fed on (1\%) of black pepper revealed significantly the heaviest body weight gain and highest feed consumption and the best feed conversion ratio as compared to control group. This might be due to that black pepper affects the absorption power, decrease material transit velocity and increase digestive enzymes activity and increased chicks dietary and weight gain due to presence of Piperazine citrate in black pepper (Al-Kassie et al. 2011). Kana et al. (2017) recorded higher BW and BWG in broiler chickensfed on ration supplemented with $0.2 \%$ of $T$. tetraptera during growing phase which is in line with the studies of Taxi et al. (2014) at finishing phase of broiler chickens with $1 \%$ black pepper. Al-Mufarrej et al. (2019) also recorded improvement in weight and feed conversion in broiler chickens fed $0.2 \%$ cloves as additives. This improvement of the BW could be due to the antimicrobial and antioxidant activities of this spice. The significant effect of phytogenic inclusion on growth performance of broiler chickens at this phase could be due to differences in age of the birds as a result of a more developed digestive system, capable of enhanced nutrient utilization resulting in improved performance (Upadhaya et al., 2016). Ocak et al. (2008) also reported higher body weight at $42 \mathrm{~d}$ of age as well as higher WG from 7 to 35 days of age in broilers fed diet containing peppermint and thyme compared to the control. It was observed that the three test ingredients had improvement on growth performance but inclusion of cloves buds is better. This is due to previous studies that phytogenic plants activities are dependent on the active ingredients present in particularly essential oils and its components could exert antimicrobial properties in the gut of animals (Al-Kassie, 2010; Lee et al., 2004).

Results of feeding different Phytogenic plants affected significantly the live weight and Plucked weight but had no effect on dressing percentages and cut parts (breast, thigh, wing and drumstick) of broiler chickens. The observed result shows that broilers fed diet containing cloves had higher live weight and plucked weight compared to other treatments.The effect of feeding broiler chicks on diets containing different levels of black

Journal of the Faculty of Agriculture and Veterinary Medicine, Imo State University Owerri website: www ajol.info; Attribution: Non-commercial CC BY-NC 
pepper as natural feed additive on carcass characteristics were reported by Tazi et al. (2014), with the results which indicated that group supplemented with $1.0 \%$ of black pepper had significantly heaviest values for body weight gain, feed intake, dressing, best feed conversion ratio, and commercial cuts percentages such as breast, drumstick and thigh. So also, the of cloves Marcinčák et al. (2011) recorded higher body weight, better feed con-version, higher carcass yield and higher breast and thigh weight in broiler chickens fed clove buds. While improvement in carcass was also recorded in broiler chickens fed by Kana et al. (2017). It is expected that the dietary inclusion of plant extracts would improve carcass yield as a result of better dietary amino acid digestion, which would favor muscle deposition, this agreed Windisch et al. (2008) report that phytobiotics increased stabilization of intestinal health, animals are less exposed tomicrobial toxins and other undesired microbial metabolites such as ammonia and biogenic amines. As a result, animals are relatively relieved from immune defense stress during critical situations and there is increase availability of essentialnutrients for absorption, thereby helping the animals to grow better within the framework of their genetic potential. The result obtained on dietary inclusion of Syzygium aromaticum, Piper nigrum and Tetrapleura tetraptera on organs indicated that, the diets has no significant influence on liver, kidney, gizzard, lung and proventriculus of the broiler chickens. This result is consistent with studies of (Hassan et al. 2018; Amad et al. 2013) that phytobiotic inclusion in diets of broiler chickens has no significant impact of on liver, heart and gizzard of broilers.

\section{CONCLUSION}

In the present study, inclusion of Syzygium aromaticum, Piper nigrum and Tetrapleura tetraptera as feed additives had no effect on growth performance of broilers chickens at starter phase. Inclusion of these phytogenic plants resulted in improved FW and WG with improved FCR and carcass weight at finisher phase. 


\section{REFERENCES}

Abugri, D.A. and Pritchett, G. (2013). Determination of chlorophylls, carotenoids and fatty acid profiles of Tetrapleura tetraptera seeds and their health implication. Journal of Herbs Spices Medicinal Plants; 19:391-400.

Adewunmi, C.O. (1999). Medicinal Plants, parasites and snails in health. Obafemi Awolowo University, Ile-Ife, Inaugural Lecture series, 132(13) 22.

Akbarian, A, Golian, A., Kermanshahi, H., Farhoosh, R., Raji, A.R., De Smet, S. and Michiels, J. (2013). Growth performance and gut health parameters of finishing broilers supplemented with plant extracts and exposed to daily increased temperature. Spanish Journal of Agricultural Research; 11(1): $109-119$. https://doi.org/10.5424/sjar/2013111-3392

Akin-Idowu, P. E., Ibitoye, D.O., Ademoyegun, O.T. and Adeniyi, O.T. (2011). Chemical composition of the dry fruit of Tetrapleura tetraptera and its potential impact on human health. Journal of Herbs Spices and Medicinal Plants; 17: 52-61. https://doi.org/10.1080/10496475.2011.560087

Al-Kassie, G.A.M., AL-Nasrawi, M. A.M and Ajeena, S.J. (2011). The Effects of using hot red pepper as a diet supplement on some performance traits in broiler. Pakistan Journal of Nutrition, 10 (9): 842-845. https://doi.org/10.3923/pjn.2011.842.845

Al-Kassie, G. A. M. (2010). The Effect of Thyme and Cinnamon on the Microbial Balance in Gastro Intestinal Tract on Broiler Chicks. International Journal of Poultry Science, 9:495-498.

Amad, A.A, Wendler K.R, andZentek J. (2013). Effects of a phytogenic feed additive on gro wth performance, selected blood criteria andjejunal morphology in broiler chickens. $E$ mir Journal of Food and Agriculture, 25:549-554. https://doi.org/10.9755/ejfa.v25i7.12364

Al-Mufarrej, S. I., Fazea, E. H., Al-Baadani, H. H. and Qaid, M.M. (2019). Effects of clove powder supplementation on performance, blood biochemistry, and immune responses in broiler chickens. South African Journal of Animal Science; 49 (5): 835-844. https://doi.org/10.4314/sajas.v49i5.6

Borazjanizadeh, M., Eslami, M., Bojarpour, M., Chaji, M. and Fayazi, J. (2011). The effect of clove and oregano on economic value of broiler chicken diet under hot weather of Khuzesta. Journal of Animal and Veterinary Advances 10(2):169-173. https://doi.org/10.1046/j.1472-765X.2003.01285.X

Burt, S.A. and Reinders R.D. (2003). Antibacterial activity of selected plant essential oils against Escherichia coli O157:H7. Letter of Applied Microbiology, 36(3):162-167.

Cross, D. E., Mcdevitt, R. M., Hillman, K. and Acamovic. T. (2007). The effect of herbs and their associated essential oils on performance, dietary digestibility and gut microflora in chickens from 7 to 28 days of age. British Poultry Science; 48:496-506. https://doi.org/10.1080/00071660701463221

Journal of the Faculty of Agriculture and Veterinary Medicine, Imo State University Owerri website: www ajol.info; Attribution: Non-commercial CC BY-NC 
Duessel, S., Heuertz, R. M. and Ezekiel, U. R. (2008). Growth inhibition of human; colon cancer cells by plant compounds. Clinical Laboratory Science, 21: 151-7

Elagib, H.A.A., El-Amin, W.I.A., Elamin, K.M. and Malik, H.E.E. (2013). Effect of dietary garlic (Allium sativum) supplementation as feed additive on broiler performance and blood profile. Journal of Animal Science Advances, 3: 58-64. https://doi.org/10.5455/jasa.20130219104029

Google Earth, 2019. http/ www. Google, earth

Hafeez, A., Manner, K., Schieder, C., and Zentek, J. (2016). Effect of supplementation of phytogenic feed additives (powdered vs. encapsulated) on performance and nutrient digestibility in broiler chickens. Poultry Science, 95:622-629.

Hippenstiel, F., Abdel-Wareth, A.A., Kehraus, S. and Sudekum, K.H. (2011). Effects of selected herbs and essential oils, and their active components on feed intake and performance of broilers - a review. ArchivfürGeflügelkunde, 75:226-234.

Hong, J.C., Steiner, T., Aufy, A., and Lien, T.F. (2012). Effects of supplemental essential oil on growth performance, lipid metabolites and immunity, intestinal characteristics, micro biota and carcass traits in broilers. Livestock Science, 144:253-262. https://doi.org/10.1016/j.livsci.2011.12.008

Jensen, J. F. (1984). Method of dissection of broiler carcass description of parts. Page 32 in World's Poultry Science Association Eur. Fed. Work. Group V. Papworth's Pendragon Press, Cambridge, UK.

Kana, J. R., Mube, K. H., Ngouana, T. R., Komguep, R., Yangoue, A., Tsafong, F and Teguia, A. (2017). Growth performances and serum biochemical response of broiler chickens fed on diet supplemented with Tetrapleura tetraptera fruit powder as substitute to antibiotic growth promoters. International Journal of Innovation and Applied Studies, 21(1)

Kim, Y.S., Hwang, J.W., Sung, S.H., Jeon, Y.J., Jeong, J.H., Jeon, B.T., Moon S.H. and Park, P.J. (2015). Antioxidant activity and protective effect of extract of Celosia cristata L. flower on tert-butyl hydroperoxide-induced oxidative hepatotoxicity. Food Chemistry, 68: 572-579. https://doi.org/10.1016/j.foodchem.2014.07.106

Kroismayr, A., Steiner, T. and Zhang, C. (2006). Influence of a phytogenic feed additive on performance of weaner piglets (Abstract). Journal of Animal Science, 84: 329.

Lee, K. W., Everts, H. and Beynen. A. C. (2004). Essential oil in broiler nutrition. Poultry Science; 3:738-752. https://doi.org/10.3923/ijps.2004.738.752

Marcinčák, S., Popelka, P., NevijoZdolec, N., Mártonová, M., Šimková, J., Dana Marcinčáková, D. (2011). Effect of supplementation of phytogenic feed additives on performance parameters and meat quality of broiler chickens. Slovakia Veterinary Research, 48 (1): 27-34. 
Monika, M., Stefanie, H. and Alois, J. (2010). Anti-inflammatory activity of extracts from fruits, herbs and spices. Food Chemistry, 122: 987-996.

Mountzouris, K.C., Paraskevas, V., Tsirtsikos, P., Palamidi, I., Steiner, T., and Schatzmayr, G., (2011). Assessment of a phytogenic feed additive effect on broiler growth performance, nutrient digestibility and caecalmicroflora composition. Animal Feed Science and Technology; 168:223-231. https://doi.org/10.1016/j.anifeedsci.2011.03.020

Mahrous, H.S., El-Far, A.H., Sadek, K.M and Abdel-Latif, M.A. (2017). Effects of different levels of clove bud (Syzygium aromaticum) dietary supplementation on immunity, antioxidant status, and performance in broiler chickens. Alexandra Journal of Veterinary Sciences, 54, 29-39.

Nasir, Z. and Grashorn. M.A. (2010). Effects of Echinacea purpurea and Nigella sativa supplementation on Broiler performance, carcass and meat quality. Journal Animal and Feed Science, 19:94-104. https://doi.org/10.22358/jafs/66273/2010

N. R. C. National Research Council (1994). Nutrient Requirements of Poultry, 9th Ed. National Academy Press. Washington, DC.

Ocak, N., Erener, G., Burakak, F., Sungu, M., Altop, A. and Ozmen, A. (2008). Performance of broilers fed diets supplemented with dry peppermint (Mentha piperitaL.) or thyme (Thymus vulgaris L.) leaves as growth promoter source. Czeck Journal of Animal Science; 53:169-175.

Onu, P.N. (2010). Evaluation of two herbal spices as feed additives for finisher broilers. Biotechnology in Animal Husbandry, 26 (5-6): 383-392. https://doi.org/10.2298/BAH1006383O

Reisinger, N., Steiner, T., Nitsch, S., Schatzmayr, G. and Applegate, T. J. (2011). Effects of a blend of essential oils on broiler performance and intestinal morphology during coccidial vaccine exposure. The Journal of Applied Poultry Research, 20:272-283. https://doi.org/10.3382/japr.2010-00226

SAS Institute. (2000). SAS/STAT(R) Inc. User's Guide, Version 9, SAS Institute, Inc. Cary, NC.

Schone, F., Vetter, A. and Hartung, H. (2006). Effect of essential oils from fennel (Foeniculaetheroleum) and caraway (Carviaetheroleum) in pigs. Journal of Animal Physiology and Animal Nutrition 90:500-10. https://doi.org/10.1111/j.14390396.2006.00632.x

Shafi, PM, Rosamma, MK, Jamil, K, and Reddy, P.S. (2002). Antibacterial activity of S. cumini and S. travancoricum leaf essential oils. Fitoterapia, 73: 414-416. https://doi.org/10.1016/S0367-326X(02)00131-4

Tazi, S.M.E., Mukhtar, M.A., Mohamed, K. and Tabidi, M.H. (2014). Effect of using black pepper as natural feed additive on performance and carcass quality of broiler chicks. International Journal of Pharmaceutical Research and Analysis, 4: 108-113

Journal of the Faculty of Agriculture and Veterinary Medicine, Imo State University Owerri website: www ajol.info; Attribution: Non-commercial CC BY-NC 
Upadhaya, S.D., Kim, S.J. and Kim, I.H. (2016). Effects of gel-based phytogenic feed supplement on growth performance, nutrient digestibility, blood characteristics and intestinal morphology in weanling pigs. Journal Applied Animal Research; 44: 384 389. https://doi.org/10.1080/09712119.2015.1091334

Windisch, W., Schedle, K., Plitzner, C., Kroismayr, A. (2008). Use of phytogenic products as feed additives for swine and poultry. Journal of Animal Science; 86: 140-8. https://doi.org/10.2527/jas.2007-0459 


\section{APPENDIX}

Table 1: Diet composition of the experimental broiler starter chickens

\begin{tabular}{lllll}
\hline Ingredients & $\mathrm{T} 1$ & $\mathrm{~T} 2$ & $\mathrm{~T} 3$ & $\mathrm{~T} 4$ \\
\hline Maize & 54.00 & 54.00 & 54.00 & 54.00 \\
Soya bean meal & 30.00 & 30.00 & 30.00 & 30.00 \\
Vegetable oil & 1.00 & 1.00 & 1.00 & 1.00 \\
Wheat offal & 6.00 & 5.00 & 5.00 & 5.00 \\
Fishmeal & 3.00 & 3.00 & 3.00 & 3.00 \\
Bone meal & 3.00 & 3.00 & 3.00 & 3.00 \\
Limestone & 2.00 & 2.00 & 2.00 & 2.00 \\
Salt & 0.25 & 0.25 & 0.25 & 0.25 \\
*Premix & 0.30 & 0.30 & 0.30 & 0.30 \\
Methionine & 0.20 & 0.20 & 0.20 & 0.20 \\
Lysine & 0.25 & 0.25 & 0.25 & 0.25 \\
Syzygium aromaticum & - & 1.00 & - & - \\
Piper nigrum & - & - & 1.00 & - \\
Tetrapleuratetreptera & - & - & - & 1.00 \\
\hline Total & 100 & 100 & 100 & 100 \\
Determined analysis $(\%)$ & & & & \\
Crude protein & 22.43 & 21.58 & 21.5 & 21.42 \\
Crude fibre & 2.05 & 3.85 & 3.76 & 4.06 \\
Ether extract & 3.85 & 3.63 & 3.59 & 3.54 \\
Ash & 3.47 & 4.11 & 4.17 & 3.25 \\
\hline Starter & & & & \\
\hline
\end{tabular}

*Starter premix: - Vit. A 10,000,000 (IU), Vit. D3 2,000,000 (IU), Vit. E 23,000(mg), Vit K 3(mg), Vit B1 1,800 (mg), Vit. B2 5,500 (mg), Niacin 27,500 mg, Pantothenic acid 7,500mg, Vit. B6 3,000mg, Vit.B12 15mg, Folic acid 750mg, Biotin H2 60mg, Chlorine chloride 300,000mg, Cobalt 200mg, Copper 3,000mg, Iodine 1,000mg, Iron 20,000mg, Manganese 40,000(mg), Selenium 200mg, Zinc 30,000mg. T1 - without Phytogenic inclusion, T2 - with Syzygium aromaticum (Cloves), T3 - with Piper nigrum (Black pepper), T4 - with Tetrapleuratetraptera (Prekese). 
Journal of Agriculture and Food Sciences

W. A. Olayemi; G. A. Williams; O.P. Olatidoye $\&^{37}$

Volume 18, Number 2, October 2020, pp 26 - 38.

E.O. Omofunmilola

Table 2: Diet composition of the experimental broiler finisher chickens

\begin{tabular}{lllll}
\hline Ingredients & $\mathrm{T} 1$ & $\mathrm{~T} 2$ & $\mathrm{~T} 3$ & $\mathrm{~T} 4$ \\
\hline Maize & 58.00 & 58.00 & 58.00 & 58.00 \\
Soya bean meal & 25.00 & 25.00 & 25.00 & 25.00 \\
Vegetable oil & 2.00 & 2.00 & 2.00 & 2.00 \\
Wheat offal & 7.00 & 6.00 & 6.00 & 6.00 \\
Fishmeal & 2.00 & 2.00 & 2.00 & 2.00 \\
Bone meal & 2.00 & 2.00 & 2.00 & 2.00 \\
Limestone & 3.00 & 3.00 & 3.00 & 3.00 \\
Salt & 0.30 & 0.30 & 0.30 & 0.30 \\
*Premix & 0.30 & 0.30 & 0.30 & 0.30 \\
Methionine & 0.20 & 0.20 & 0.20 & 0.20 \\
Lysine & 0.20 & 0.20 & 0.20 & 0.20 \\
Syzygium aromaticum & - & 1.00 & - & - \\
Piper nigrum & - & - & 1.00 & - \\
Tetrapleuratetreptera & - & - & - & 1.00 \\
\hline Total & 100 & 100 & 100 & 100 \\
Determined analysis $(\%)$ & & & & \\
Crude protein & 20.33 & 20.33 & 20.33 & 20.33 \\
Crude fibre & 4.08 & 3.67 & 3.56 & 3.45 \\
Ether extract & 3.91 & 3.57 & 3.52 & 4.36 \\
Ash & 3.04 & 2.91 & 2.85 & 2.75 \\
\hline
\end{tabular}

*Finisher premix: - Vit. A 10,000,000 (IU), Vit. D3 2,000,000 (IU), Vit. E 23,000(mg), Vit. K 3(mg), Vit. B1 1,800 (mg), Vit. B2 5,500 (mg), Niacin 27,500 mg, Pantothenic acid 7,500mg, Vit. B6 3,000mg, Vit. B12 15mg, Folic acid 750mg, Biotin H2 60mg, Chlorine chloride 300,000mg, Cobalt 200mg, Copper 3,000mg, Iodine 1,000mg, Iron 20,000mg, Manganese 40,000(mg), Selenium 200mg, Zinc 30,000mg. T1 - without Phytogenic inclusion, T2 - with Syzygium aromaticum (Cloves), T3 - with Piper nigrum (Black pepper), T4 - with Tetrapleura tetraptera (Prekese).

Table 3: Growth performance of broiler starter chickens fed diets with phytobiotics

\begin{tabular}{lllllll}
\hline Parameters (g) & T1 & T2 & T3 & T4 & SEM & P-Value \\
Initialbody weight & 48.30 & 48.40 & 47.57 & 48.59 & 0.16 & 0.110 \\
Final bodyweight & 773.33 & 813.10 & 787.50 & 772.92 & 7.24 & 0.360 \\
Total weight gain & 725.03 & 764.70 & 739.93 & 724.33 & 7.24 & 0.360 \\
Daily feed intake & 55.65 & 56.41 & 54.98 & 55.05 & 0.38 & 0.770 \\
Total feed intake & 1558.47 & 1588.76 & 1539.72 & 1541.63 & 10.23 & 0.560 \\
FCR & 2.15 & 2.08 & 2.08 & 2.13 & 0.02 & 0.720 \\
\hline
\end{tabular}

Mean on the same row without superscript are similar ( $>>0.05)$ SEM- Standard error of mean, T1- without phytogenic inclusion, T2- with Syzygium aromaticum, T3- with Piper nigrum, T4 - with Tetrepleura tetraptera. FCR-Feed conversion ratio 
Journal of Agriculture and Food Sciences

W. A. Olayemi; G. A. Williams; O.P. Olatidoye $\&^{38}$

Volume 18, Number 2, October 2020, pp 26 - 38 .

E.O. Omofunmilola

Table 4: Growth performance of broiler finisher chickens fed diets with phytobiotices

\begin{tabular}{lcccccc}
\hline Parameters $(\mathrm{g})$ & $\mathrm{T} 1$ & $\mathrm{~T} 2$ & $\mathrm{~T} 3$ & $\mathrm{~T} 4$ & SEM & P-Value \\
\hline Initial Weight & 773.33 & 813.10 & 787.50 & 772.92 & 7.24 & 0.36 \\
Final Weight & $1519.0^{\mathrm{b}}$ & $1711.00^{\mathrm{a}}$ & $1551.00^{\mathrm{b}}$ & $1608.33^{\mathrm{ab}}$ & 21.98 & 0.03 \\
Weight Gain & $745.67^{\mathrm{b}}$ & $897.90^{\mathrm{a}}$ & $765.50^{\mathrm{b}}$ & $835.42^{\mathrm{ab}}$ & 19.74 & 0.04 \\
Daily Feed Intake & 84.83 & 85.45 & 85.61 & 86.12 & 0.93 & 0.45 \\
Total Feed Intake & 2375.24 & 2392.6 & 2397.08 & 2411.36 & 25.94 & 0.48 \\
FCR & $3.19^{\mathrm{a}}$ & $2.67^{\mathrm{d}}$ & $3.13^{\mathrm{b}}$ & $2.89^{\mathrm{c}}$ & 0.10 & 0.04 \\
\hline
\end{tabular}

a,b,c,d Mean on the same row having different superscript are significantly $(p<0.05)$ different. SEM- Standard error of mean, T1 - without phytogenic inclusion, T2 - with Syzygium aromaticum, T3 - with Piper nigrum, T4 - with

Tetrepleura tetraptera.FCR-Feed conversion ratio

Table 5: Carcass and organ weights of broiler finisher chickens fed diets with Phytobiotics

\begin{tabular}{lcccccc}
\hline Parameters (g) & T1 & T2 & T3 & T4 & SEM & P-Value \\
Live weight & $1519.00^{\mathrm{b}}$ & $1711.00^{\mathrm{a}}$ & $1551.00^{\mathrm{b}}$ & $1608.33^{\mathrm{ab}}$ & 21.98 & 0.03 \\
Plucked weight & $1493.16^{\mathrm{b}}$ & $1683.63^{\mathrm{a}}$ & $1529.70^{\mathrm{b}}$ & $1584.32^{\mathrm{ab}}$ & 19.53 & 0.04 \\
Dressing \% & 72.96 & 68.06 & 71.82 & 64.98 & 1.91 & 0.72 \\
Cut parts & & & & & & \\
Breast & 4.23 & 4.61 & 4.75 & 4.72 & 0.14 & 0.82 \\
Thigh & 8.61 & 8.95 & 9.77 & 9.75 & 0.32 & 0.53 \\
Drumstick & 8.62 & 9.20 & 8.67 & 9.62 & 0.26 & 0.77 \\
Wing & 10.57 & 10.87 & 10.40 & 11.71 & 0.23 & 0.47 \\
Back & 6.72 & 7.25 & 6.95 & 7.44 & 0.19 & 0.84 \\
Head & 3.03 & 3.06 & 3.02 & 2.77 & 0.11 & 0.83 \\
Neck & $2.17^{\mathrm{ab}}$ & $1.90^{\mathrm{b}}$ & $2.74^{\mathrm{a}}$ & $2.25^{\mathrm{ab}}$ & 0.11 & 0.04 \\
Shank & 1.92 & 1.88 & 1.95 & 2.01 & 0.07 & 0.98 \\
Organ weights & & & & & & \\
Heart & 0.17 & 0.17 & 0.15 & 0.20 & 0.01 & 0.52 \\
Liver & 4.05 & 4.28 & 4.26 & 4.11 & 0.13 & 0.98 \\
Kidney & 0.86 & 0.66 & 1.05 & 0.80 & 0.08 & 0.63 \\
Gizzard & 4.58 & 4.87 & 5.13 & 4.57 & 0.16 & 0.79 \\
Proventriculus & 0.26 & 0.26 & 0.27 & 0.24 & 0.01 & 0.57 \\
Lung & 0.16 & 0.18 & 0.17 & 0.17 & 0.01 & 0.90 \\
\hline
\end{tabular}

a,b,c,d Mean on the same row having different superscript are significantly $(\mathrm{p}<0.05)$ different. SEM- Standard error of mean, T1-without phytogenic inclusion, T2-with Syzygium aromaticum, T3-with Piper nigrum, T4-with Tetrepleura tetraptera. FCR-Feed conversion ratio 